https://doi.org/10.21670/ref.1906027

Articles

\title{
Narratives of border reinforcement: The role of knowledge and communications power
}

\author{
Narrativas de reforzamiento de la frontera: El rol del \\ saber y el poder de las comunicaciones
}

Sergio Peña ${ }^{\text {a* }}$ https://orcid.org/0000-0002-9505-4057

a El Colegio de la Frontera Norte, Dirección Regional Noroeste, Ciudad Juárez, Chihuahua, México, e-mail: spena@colef.mx

\begin{abstract}
The general objective of this paper is to analyze and explain the paradox of why objective knowledge based upon "facts and hard data" has been insufficient to forge a narrative, particularly in the U.S. side, that would lead towards a deeper cooperation and make the U.S.-Mexico border more fluid, functional and integrated. The main question is: why the "re-territorialization" narrative of reinforcing differences and solidifying the border has prevailed? The theoretical framework that guides this analysis is the Aristotelian concept of "phronesis" or "practical wisdom" to settle beliefs that cannot be reached through an objective scientific rationality. The issue of power is of great interest in this analysis; particularly, the paper explores the relationship between knowledge and communications power as explanatory factors to understand the forging of a narrative of reinforcing borders. The conclusion is that the military-surveillance industrial complex has been the most influential actor behind the kind of knowledge that shape border policy compared to academic and scientific knowledge.
\end{abstract}

Received on November 1, 2018. Accepted on April 11, 2019. Published on May 23, 2019.

${ }^{*}$ Corresponding author: Sergio Peña, e-mail spena@colef.mx

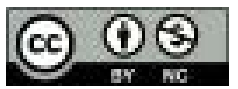

This work is licensed under a Creative Commons Attribution-NonCommercial 4.0 International License.
Keywords: knowledge and power, United States-Mexico border, border and power, communications power.

\section{Resumen}

El objetivo del artículo es analizar y explicar la paradoja del por qué el saber objetivo basado en "datos y hechos" es insuficiente para crear una narrativa que conduzca a una integración y cooperación más profunda, y de esa manera producir una frontera más fluida, funcional e integrada. La pregunta central es ¿Por qué la narrativa de reterritorialización, que refuerza las diferencias y solidifica la frontera, ha prevalecido? El marco teórico que guía el análisis se fundamenta en el concepto de frónesis, que es un tipo de saber práctico a través del cual los actores sociales llegan a un acuerdo cuando este no puede lograrse

CITATION: Peña, S. (2019). Narratives of border reinforcement: The role of knowledge and communications power (Narrativas de reforzamiento de la frontera: El rol del saber y el poder de las comunicaciones). Estudios Fronterizos, 20, e027. doi:https://doi. org/10.21670/ref.1906027 
por medio de la racionalidad científica. El tema de poder juega un rol importante en el análisis - particularmente, la relación entre el saber y el poder de la comunicación para articular una narrativa de diferenciación. La conclusión es que el poder de la industria militar y de vigilancia ha tenido mayor influencia en darle forma a la política fronteriza comparada con el poder de la academia y el conocimiento científico.

Palabras clave: conocimiento y poder, frontera Estados Unidos-México, frontera y poder, poder de las comunicaciones.

\section{Introduction}

The U.S.-Mexico border in recent decades has been the subject of competing narratives and rationalities. On the one hand, a discourse derived from neoliberal processes of globalization implies policies to "de-territorialize" borders and construct a transnational community where borders are liquefied or easier to cross. On the other hand, a "re-territorialization" discourse emphasizing differences and strengthening the notion of the border as barrier and threat, thus solidifying borders (Bauman, 2007, pp.1-26; Bauman, 2012, pp. 1-15). The election of Donald J. Trump is an attempt to return to the Euclidian geographical view of borders as a physical line and a process of reinforcing differentiation to sort out those who belong and those who are exclude (Newman, 2003).

The main question I am aiming to answer is why the "re-territorialization" narrative of reinforcing differences and solidifying the border has prevailed, despite the fact that there is evidence (trade, foreign direct investment, etc.) showing that a more seamless border is an important economic asset for both countries? The general objective of this paper is to analyze and explain the paradox of why objective knowledge based upon "facts and hard data" has been insufficient to forge a narrative, particularly in the U.S. side, that would lead towards a deeper cooperation and make the U.S.-Mexico border more fluid, functional and integrated. The paper purpose is mainly theoretical and draws in some empirical facts to illustrate rather than to prove.

I acknowledge that there is a vast body of knowledge produced by international relations scholars, among others, that could be helpful. However, my goal is to test Flyvbjerg (2001) proposal of employing "phronesis" as theoretical approach to explain the reinforcement of the border as a barrier. The concept of phronesis (Flyvbjerg 2001, pp. 110-128) is based on the Aristotelian idea of "practical wisdom" and it is one of the ethical virtues that Aristotle identifies as a type of knowledge. According to Flyvbjerg (2001, pp. 25-37) social sciences has come to a point of facing nihilism and lacking any meaning due to current sciences wars (Ross, 1996) between positivist and relativist philosophies. Phronesis, according to Bent Flyvbjerg (2001, pp. 110-128) can provide new meaning to the social sciences and move beyond the ontological dichotomy of objectivity and cultural relativism. Phronesis takes into consideration social relationships around issues of power and "value rationality" to provide a more realistic ontological explanation of the social world. According to Aristotle (2009, pp. 105-107) practical wisdom or Phronesis is the kind of reason that is fundamental in a society, to settle beliefs through deliberation, when science or pure objectivity fails to do so. One basic premise derived from a phronetic analysis is that power is key to rationalizing and shaping a reality (Flyvbjerg, 2001, pp. 110-128). 
The way power is deployed and exercised to rationalize and shape a reality is the main theme of the paper. One of the limitations of Flyvbjerg (2001, pp. 88-109) is that lacks a theorization of power and provides very limited explanation into the kind of power that is relevant to take into consideration (Forester, 2001). I argue that by coupling phronetic knowledge and communications power provide a useful line of inquiry; particularly, exploring how knowledge about the object (i.e. border) is being produced, by whom and for what purpose? Communications power (Castells, 2007; Castells, 2013, pp. 10-53) is used as a way to uncover how a message is being produced in the network society in order to shape the "truth" about the object (i.e. the border); the role of traditional mass media and social media are of particular interest. The main hypothesis is that the military-surveillance industrial complex has been the most influential actor behind the kind of knowledge that shape border policy. Furthermore, Trump's election based on anti-immigrant, anti-trade and anti-Mexican views, has shown the power of communications, through social media in the U.S., to shape minds and opinions about the border in a deliberative setting. As it will be discussed later, the election of Trump is an example of continuity to illustrate the power of communication, such as social media, as a tool to reinforce symbolic borders through material means such as physical barriers and military tactics, rather than a platform of pragmatic truthful debate where people, through intersubjective means, come to an "agreement of the situation" as in a Habermasian' view of communicative action (Habermas, 1985).

The remainder of the paper is divided into three sections. The first section offers an analysis of how border scholars have study the issues of power and rationality and borders in order to set up my point of departure. The following section focuses on answering the guiding questions that Flyvbjerg (2001, pp. 53-65) proposes which are: 1) Where are we going? 2) Who gains and who loses, by which means of power? This is the most important question. 3) Is it desirable? and 4) what should be done? The final section provides some conclusions and reflections.

\section{Borders, Knowledge and Power: Theoretical Framework}

Before delving into the issues of power at the U.S.-Mexico border, it is important to review some of the arguments (Heyman, 2017; Newman, 2003, p. 22; Paasi, 2010; Paasi, 2011; Salter, 2006; Slack, Martínez, Lee \& Whiteford, 2016; Sparke, Sidaway, Bunnell \& Grundy-Warr, 2004) being made in regards to power and borders. Sparke et al. (2004, p. 488 citing O'Tuathail), argue that territory needs to be re-conceptualized as a regime of practices triangulated between institutionalization of power, materialization of place and idealization of 'people's. Paasi (2011, pp. 11-12) argues that little attention has been paid to the issue of how social power is involved in the region building process; the author concludes that regional identities in practice:

....are typically discourses of scientists, politicians, administrators, cultural activists or entrepreneurs that aim to distinguish a region from some others. Such classifications are inevitably based on certain choices, where some elements are chosen to constitute and identity narrative and some others are excluded. Thus they are expressions of power in delimiting, naming, and symbolizing space and groups of people (Passi, 2011, p. 14). 
Newman (2003, p. 22), along the same lines, argues that borders are institutions that govern the extent of "inclusion/exclusion" and power elites decide who is excluded and "[they] view the border as an institution which protects those who are on the 'inside' or are 'here' from the (perceived) negative impact of those who have been excluded and are on the 'outside' or are 'there'." (Newman, 2003, p. 14). Slack et al. (2016, p. 8) focuses on how policies of "deterrence strategy" are shape by State power with a militarized logic with emphasize on inflicting "pain, suffering, and trauma as a deterrence". Heyman (2017, p. 46) takes a critical and relational approach, and shows how power attempts to deal with the paradox of "uneven and combined development at the border", where "managerialist elites" views, of a more functionalist space, are in competition with right-wing views focus on symbolic borders and policing. In summary, the review shows that borders are social constructs based on people's subjectivities and where politics and power relations are the arenas to settle the differences and put into action (i.e. policies) the ideas. Salter (2006) moves beyond the analysis of power from the macro perspective of border making into an analysis of how power is put into action by using Foucault's concepts of biopolitics as practices of inclusion/exclusion. Salter (2006, p. 173) argues that the concept of biopolitics helps explain and understand the way in which obedience and choice are structured through a power/knowledge network. Anti-terrorist policies put in place to screen vetting people have made scholars pay attention to power relationships between the sovereign and the control of bodies; this biopolitical power is exercised at all sorts of borders crossings including airports in the form of power technologies such as biometrics, finger printing, eye scans, etc. (Salter 2006, pp. 169-174).

Bauman (2012, pp. 8-11) argues that one of the main attributes of modernity was how time and space is conceived. Whereas space was fixed, time was dynamic. The panopticon, according to Bauman (2012, pp. 9-11), is an example of modern power associated with the need of professional surveillance. Border surveillance and security are examples of this solid modernity. Border security institutions, such as the U.S. Border Patrol and Immigration and Customs Enforcement (ICE) are the examples of solid institutions that embedded modern panopticon power of the nation-State.

In the above analyses border reinforcement (i.e. differentiation) involves power relations. Power helps to shape and rationalize narratives that portray borders as threats, out of control, "no man's land," etc. The above analyses explain how power is exercised to institutionalize borders as processes of differentiation and exclusion. The point of departure of this paper, regarding power, is that I anchor the present analysis of power and borders with the conceptual framework of Foucault (1980, pp. 55-165) and Bourdieu (2003, pp. 220-228) regarding the relationship between knowledge and power. Also, I used the idea of Castells (2007; Castells, 2013, pp. 10-53) around the topic of communications power.

Foucault (1980, pp. 55-165) and Bourdieu's (2003, pp. 220-228) ideas are useful to explore the issue of who decides which knowledge is more accepted by the social corpus to produce a narrative that will drive policy making. And Castells' idea (2007; Castells, 2013, pp. 10-53) of communications power will be used to explain the role of mass and social media; particularly the success of Donald Trump, in the use of social media to get elected by employing a narrative of differentiation around an anti-NAFTA and anti-Mexican discourse. 
Foucault's (1980, pp. 78-108) concepts of dominant and "subjugated" knowledge, and Bourdieu's (2003, pp. 163-170; Bourdieu, 2014, pp. 162-175) concept of "symbolic power" are helpful, and provide a bridge to Castells (2007; Castells, 2013, pp. 10-53) idea of communications power. Both, Foucault (1980, pp. 5-165) and Bourdieu (2003, pp. 163-170; Bourdieu, 2014, pp. 162-175), challenge the idea that knowledge production is an objective, value free enterprise as positivists social science portraits; rather knowledge is the product of power relations, and those in power are the ones who decide which knowledge becomes valid and considered mainstream and accepted by society. Foucault (1980, p. 82) explains how some ideas or forms of producing knowledge become predominant over others forms of "subjugated knowledges...that have been disqualified as inadequate to their task or insufficiently elaborated: naive knowledges, located low down in the hierarchy, beneath the required level of cognition or scientificity". Examples of the subjugated knowledge include "commonsense knowledge, popular knowledge", etc. Bourdieu (2014, pp. 162-175) explores the question of how the dominant dominates and he argues that is through symbolic power that the dominant creates relations of force as well as relations of meaning; this kind of power is exercised in "invisible way that people are unaware of its very existence [and] the very exercise of this power depends on this lack of awareness".

Foucault (1980, pp. 109-133) puts the emphasis on how some narratives through knowledge-power relations become dominant, whereas Bourdieu (2014, pp. 162-175) highlights the ways how those narratives of power through share meanings become part of the social body. Thus, knowledge-power and discourses are linked and through different channels of communications need to be reproduced. Castells (2007, pp. 240243; Castells, 2013, pp. 10-53) argues that political communication as a means to create a social narrative and action has changed dramatically by the emergence of social media. The typical channels of communication such as mass media (newspapers, TV, radio) no longer have the monopoly of being gatekeepers or intermediate filters of news and narratives between politicians and society; social media has provided new means of direct network communication between politics and society, often bypassing traditional media. This new venue has changed dramatically how narratives are being produced, reproduced and contested. The election of Trump, due to the peculiar electoral college and despite the fact that obtained fewer votes than Hillary Clinton, is an example of the power of social media as a mean to disseminate a narrative of differentiation that a considerable percentage of the social corpus accepted; the border wall between the U.S. and Mexico being a centerpiece of this narrative that reinforces symbolic borders. The traditional truth standards of mass media reporting based on fact checking and ethics of objective communication are confronted with other channels of mass communication (e.g. Fox News), such as social media (Breitbart News Network) where people look for opinions, of like-minded networks, to reinforce their views become accepted facts and present an alternative narrative and reality to the traditional mass media.

Figure 1 shows the analytical framework to understand the logic that drives power and action at the border. There are forms of knowledge that can be objective, subjective or intersubjective communicative processes. The idea that knowledge is power and a resource that is exercised to reinforce differentiation is emphasized. The exercise of power is instrumental; power is a mean to achieve an end of maintaining symbols that are considered mainstream (cultural traditions, language, etc.) or dominant, 
and also power is able to shape reality shutting down "counter conducts" (Foucault, 2004, pp. 191-226; Bourdieu, 2003, pp. 43-65) movements and ideas. Communications power (Castells, 2007; Castells, 2013, pp. 20-53) plays an important role in producing and reproducing those narratives that lead to exclusionary policy actions (legislation and resource allocation to reinforce a material and symbolic border).

Figure 1. Analytical framework: Power and rationality

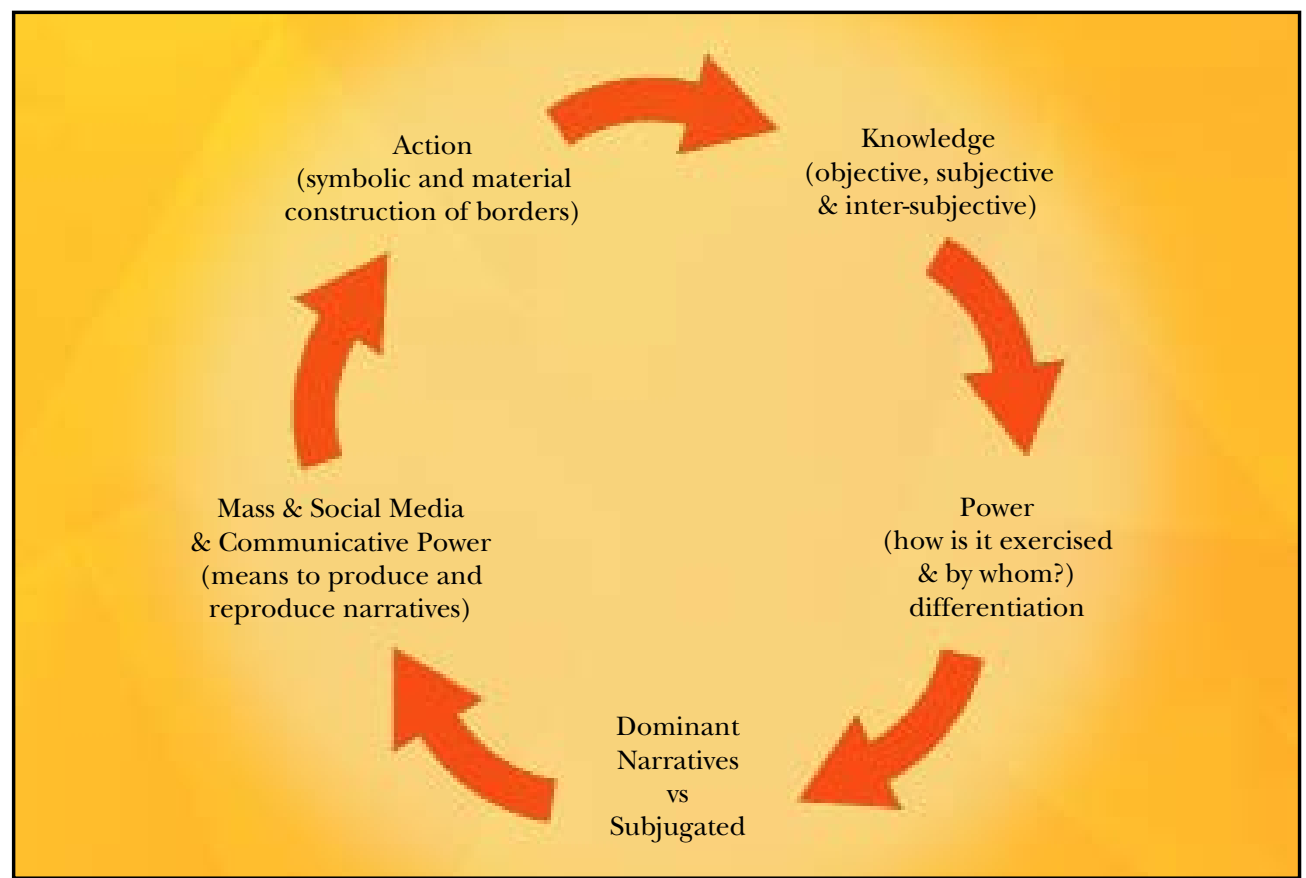

Source: Developed by the author.

The ideas of Foucault and Bourdieu are not incompatible with the idea of Aristotle's (2009, pp. 105-107) practical wisdom. Aristoteles identifies five forms of "wisdom" or reason through which people "affirm or denial truth"; these are: a theoretical one where science is the way to produce knowledge; and a practical one where deliberation is a form to create reason through practical wisdom. The other three are intuition, philosophical wisdom, and art. According to Aristotle (2009, pp. 105-107) practical wisdom is the knowledge that is form through deliberation. A subject with practical wisdom is one that is able to "deliberate" about "what sorts of thing conduce to the good life in general a capacity to act with regard to the things that are good or bad for man" (Aristotle, 2009, p. 106). In summary, practical wisdom is about things which "it is possible to deliberate" (Aristotle, 2009, p. 108).

I argue that this conceptual framework provides a route to be able to answer the four basic questions posed by Flyvbjerg (2001, pp. 53-65) that are used to explore how power is able to shape, produce and reproduce a narrative of border reinforcement and differentiation. In brief, border narratives are not necessarily driven by ontological objectivism of rational scientific wisdom but rather through practical wisdom where deliberation is a mean to construct and rationalize a narrative and where "value rationality" plays a key role. 


\section{Power at the U.S-Mexico Border: A Phronesis Approach}

Flyvbjerg (2001, pp. 53-65) proposes four questions that are relevant to operationalize phronesis as a methodological research strategy. The questions are: Where are we heading? Who wins and who loses and through which means of power? Is it desirable? What can be done? This section employs those questions as a way to organize the discussion around the issue of practical knowledge and communication powers.

As stated earlier this section's main goal is illustrative rather than seeking external validity through empirical data. The data or cases used are mostly to exemplify and strengthen the theoretical arguments developed in the paper. A detail statistical analysis of social media data is beyond the scope of this paper.

\section{Where are we Heading?}

The U.S.-Mexico border in the last few decades has experienced a dialectical process of deterritorialization and re-territorialization (Fuentes and Peña 2010) typical of globalization (Brenner, 1999; Harvey, 2006, pp. 9-68; Sassen, 2007, pp. 45-96). This is, while capital and goods flow across borders more freely; flows of unskilled labor and people, from poorer neighbors, are more restricted in general by wealthier receiving countries (Boehmer \& Peña, 2012, pp. 274-277). At the same time that infrastructure such as bridges, port facilities, etc. are upgraded and expanded to facilitate crossborder trade; fences as well as more sophisticated surveillance technology (Boyce, 2016, pp. 255-257) to detect unauthorized crossing (e.g. undocumented migrants and illicit goods) are deployed at the border (Slack et al., 2016). Sohn (2014) points out that globalization was an important driving force for states to give up some sovereignty to "transnational bureaucracies" to implement some deterritorializing process (i.e. make borders more fluid and seamless) in order to ensure the accumulation of capital. Bauman (2007, pp. 5-26; Bauman, 2012, pp. 1-15) argues that globalization is a process of "liquefying" old "solid" institutions, a process that creates negative outcomes such as uncertainty, unsafety and insecurity described as the "unholy trinity" of "modern liquidity."

The terrorist attacks on the U.S. on 09/11/2001 reinforced the sense of insecurity and brought back the nation-State by reasserting its police power (Foucault, 2004, pp. 311-361) as a key function for protecting population safety; thus, accentuated more restrictive territorial policies at the U.S.-Mexico borders to manage uncertainty and insecurity (Slack et al., 2016). The terrorist attacks have undone the limited attempts of transnationalism and cross-border multi-level governance in favor of a more traditional neo-realist approach (Morgenthau, 2014) based upon the notion of using police power to maintain control of the territory and its borders (Foucault, 2004, pp. 311-361). The U.S.-Mexico border has become one of the sceneries where security policies materialized, by making the border physically more visible and harder to cross; this is, power has been exercised to reinforce differences and separation; as Newman (2003) points out, borders are processes of differentiation and exist as an institution to protect those "inside" from the dangers of whatever is "outside" the border. 
The U.S.-Mexico border, though, never conceived in pure spatial relational terms, has reinforced the Euclidian conception of border government. According to Harvey (2006, pp. 119-148) a Euclidian conception of space emphasizes the geographic and physical attributes of demarcation; thus the border becomes a container of processes that codifies what is "in" and what is "outside" (Taylor, 2003, pp. 102-108). Differentiation policies and actions by the U.S. at the border are aimed to protect, what Bourdieu (2003, pp. 220-228) calls, the symbolic power (e.g. hegemonic language, identity, etc.) of those in control from "outside" threats (culture, terrorism, undocumented migration, drugs, undemocratic values, etc.).

The border policy, particularly after $09 / 11$, is heading towards an emphasis of border as a differentiation or a "mixophobia" (Bauman, 2007, pp. 86-93) defined by power holders in Washington and some states such as Texas and Arizona. Border reality is being shaped and defined by power holders and particularly by the "surveillanceindustrial complex" (Hayes, 2012; Lyon, 2010). Using Bauman's (2007, pp. 86-93; Bauman, 2012, pp. 182-184) concepts, I would add that the idea of a border wall is a "mixophobic" response by a segment of American society affected by the three negative aspects of globalization -uncertainty, unsafety and insecurity. Donald Trump has exploited and reinforced successfully, through social media, the anxiety of a segment of U.S. society. The narrative, that has succeeded in rationalizing the border, is that the southern border is the source of those "unholy trinity" effects; therefore it is necessary to build an "armor" to maintain the "...island of homely and cosy tranquility in a sea of turbulence and inhospitality" (Bauman, 2012, p. 182). In summary, we are heading towards a material border that separates, differentiates, expels and denies entry to those labeled as a risk (Newman, 2003, pp. 19-20) to the symbolic power, portrayed as national values; Heyman (2017) equates this policy as a "border Apartheid" in the sense that some segments of borders residents are banned from entering into the U.S. space. Trump's executive orders have identified two main groups considered a risk to the symbolic power; first, undocumented immigrants coming through the southern border (Mexicans and central Americans), and that is why a border wall is needed. Second, nationals of seven majority Muslin countries (Syria, Iraq, Iran, Somalia, Libya, Yemen and Sudan) considered being at the forefront of radical Islamism and a threat to the U.S. national security. The Trump administration recently has exploited and portrait as an "invasion" asylum seeker from Central American countries; thus, using the executive power to declare a "national emergency" at the border. Disrupting border flows and sensationalizing the problem, through mass and social media, is a way to reinforce its political message that will carry on to the next election. The democratic system and the media again will be a medium to debate and settle beliefs that cannot be settled through objective means.

\section{Who Wins and who Loses, and Through Which Means of Power?}

The goal in this section is to illustrate Foucault's idea of how power is deployed to the production of knowledge that becomes the driving force of policy-making. The knowledge that is employed to rationalize actions that at the end served some powerful interests and the reinforcing borders narrative. 
This question is answered by first looking at some key actors and asking who benefits and who loses with the implementation of the security-surveillance policies at the border. Heyman (2012, pp. 267-269) analysis is an important key to provide an answer in regards of who the winners are of the differentiation policies and reinforcing of the material border. The author explores something that is puzzling to many border scholars-why border expediency of flows, which works in favor of global capitalism, is severely undermined; Heyman (2012, pp. 263-265) concludes that resources are allocated in favor of "between-port-enforcement" over "port-operation." In other words, resources are spent in favor of interdiction operations against the "illicit economy" (Andreas, 2004, p. 648) such as drugs and human trafficking, that crosses in non-authorized locations (i.e. "between ports" of entry), instead of facilitating the flows of goods and people vetted to cross at authorized ports of entry.

I argue that global capitalism at the border in the form of maquiladora output is still profitable despite costs incurred by border crossing delays; in other words, the marginal gains from speeding flows at the border are not enough to invest in more aggressive lobbying for more efficiency at the border. A different story is the prospect of imposing a 20\% "border adjustment tax" or tariff, which could have a substantial impact, particularly, if Mexico retaliates which could disrupt the entire chain of global production. Trump even had to backtrack when in March 29, 2019 threaten to close the "damn border". However, there is another actor that profits from "between-portenforcement" refer throughout the analysis as the "surveillance-industrial complex" (Hayes, 2012). The "surveillance-industrial complex" is defined by Hayes (2012) as a "marriage of technology and security" that links governments, state agencies and corporations along the same lines of liquid surveillance. According to Hayes (2012, p. 170), citing Visiongain report, in 2010 global expenditures in national security topped $\$ 178$ billion dollars; border security in the form of perimeter surveillance and unmanned ground and aerial surveillance accounted for $\$ 15.8$ billion; the Department of Homeland Security (DHS) in the U.S. spends over one billion per year in R\&D related to security (Hayes, 2012, p. 173).

In the U.S., agencies related to the "surveillance-industrial complex" such as the DHS, the Drug Enforcement Agency (DEA), The Federal Bureau of Investigation (FBI), the Central Intelligence Agency (CIA), among others and contractors associated with putting in place surveillance technologies are the big winners. In order to put things into perspective and to have a dimension of the issue here are some facts in monetary terms. The budget for the 2016 fiscal year authorized for the DHs was \$64 858484 000 (Department of Homeland Security [DHs], 2016); the proportion of the DHS budget assigned to the Customs and Border Protection (СВP) is equal to 21\% (13 565294 000). Applying back-of-the- envelope calculations the entire spending budget of four Mexican border states -Baja California, Sonora, Chihuahua, Coahuila and Tamaulipas is roughly equivalent $(96 \%)$ to the entire budget allocated to CBP. ${ }^{1}$ The budget allocated to CBP from 2000 to 2009 increased by $230 \%$ from 1.06 to 3.50 billion and almost fourfold to 13.5 billion in 2016. Border patrol manpower doubled in a decade reaching 17 499; in 2015 reached 20183 border patrol agents; at the southern border in 1992 there were 3555 agents and in 2008 there were 15442 (334\% increase).

\footnotetext{
1 The 2016 Budget in pesos is as follows: Baja California 44402168 922.00; Sonora 54628610718.00 ; Chihuahua 62000000 000.00; Coahuila 43763068 000.00; Tamaulipas 43652521 208.00. Total budget in dollars (19 to 1 exchange rate) is equal 13076124676.21.
} 
The other side of the story is that apprehensions of undocumented migrants reached their highest point in 2000 with 1.65 million, and since then there has been a steady decline (Nunez-Neto, 2008, pp. 13-19; U.S. Customs and Border Protection 2015a). According to the Pew Research Center, Mexican net migration to the U.S. has steadily declined from 2009 to 2012; there were 5.9 million in 2012 compared to 6.4 in 2009; the explanation is that there is an increase in departures and a decline in arrivals (Passel \& D'Vera, 2014, p. 9). However, Mexico's border continues being a bridge to other migrants, particularly Central American unaccompanied children, reaching a crisis in 2014 with 68541 apprehensions of minors (U.S. Customs and Border Protection, 2015b). In 2018 and 2019 another big wave of Central American is taking place in the form of caravans; the big difference is that those migrants are families fleeing violence and seeking asylum in the U.S. instead of young, mostly males, looking for work. The "surveillance-industrial complex" such as СвP as well as those engaged in providing consulting and technology services will be greatly affected if the U.S.-Mexico border becomes seamless or "liquid" and there is not as greater a need for border surveillance; this is an important reason why narratives and discourses coming from this group of power holders will be that the border is a dangerous place, and therefore there is a need to allocating more resources in order to reinforce and make the border secure. The Trump administration is following the same policy by trying to increase manpower at the border; it has set the goal of hiring 5000 additional border patrol agents and 10000 ICE officers, in addition he wants to relax vetting hiring procedures such as polygraph test to speed up the process.

Shifting our focus to the issue of knowledge and power, I argue, that the "surveillanceindustrial complex" has been successful in steering knowledge produced at academic institutions to serve its interest and validate and solidify its power grip. Traditionally, it is thought that scientific knowledge is objective and value free, however as Bourdieu (2014, p. 163) argues, symbolic power has the characteristic of being "exercise in such an invisible way that people are unaware of its very existence and those subject to it are the first among these, since the very exercise of this power depends on this lack of awareness", while academics still believe in the objectivity and value free of their knowledge, it is clear that some academic knowledge serves power.

Thus, academia and universities in the U.S. are on the winning side with research grant money. Universities have jumped into the national security regime wagon by making applied research and scientific knowledge available to the "surveillanceindustrial complex". DHs has certified 15 programs in universities as Centers of Excellence (COEs) on homeland security science and technology, some right at the border (Hayes 2012, p. 173). For example, the University of Arizona with the University of Texas at El Paso (UTEP) co-lead the National Center for Border Security and Immigration; the National Security Studies Institute at UTEP is part of that initiative (U.S. Department of Homeland Security, 2015). A newly created center that also deals with border issues at the University of Houston is the Center for Borders, Trade, and Immigration Research (CBTIR); the others COEs focus on a variety of topics related to national security such as coastal resilience (University of North Carolina), critical infrastructure (University of Illinois, Urbana-Champaign), Artic domain awareness (University of Alaska, Anchorage), visualization and data analytics (Purdue and Rutgers), localization of explosives related threats (Northeastern University), zoonotic and animal disease defense (Texas A\&M and Kansas State University), food protection and defense institute (University of Minnesota), maritime security (Stevens Institute 
of Technology), risk and economic analysis of terrorism events (University of Southern California), study of terrorism and responses to terrorism (University of Maryland), maritime, island and remote and extreme environment security (University of Hawaii and Stevens Institute of Technology), microbial risk assessment (University of Michigan, Drexel University, and Environmental Protection Agency), coastal hazards (UNC-Chapel Hill and Jackson State University), preparedness and catastrophic event response (Johns Hopkins University), the national transportation security center of excellent composed of several institutions such as Long Island University at Riverhead, University of Arkansas, University of Connecticut, Rutgers University, Texas Southern University and Tougaloo College.

In the opposite side the research centers that focus on broader border topics such as border governance, inequality, human rights, and "human security" (Slack et al., 2016) etc. are far fewer on the U.S. side. Mexican academic institutions pay more attention to non-security and integration issues. These institutions represent what Foucault (1980, pp. 78-108) denominated "subjugated" knowledge, or in terms of power are examples of counter narratives, that have far less power to induce change and policy actions at the border, or influence a narrative and discourse at the national and binational level. A few centers on the U.S. border states such as UC-San Diego Center for USMexico Studies focusing on US-Mexico relations; San Diego State University had a binational public administration program, that was not able to survive beyond its first cohort of binational students; the School of Transborder Studies at Arizona, which is perhaps the only one offering a doctoral degree in transborder studies; centers which focuses on borderlands studies per se, Udall Center at University of Arizona focusing on environmental issues including transborder natural resources, New Mexico State University Center for Latin America and Border Studies, University of Texas at Austin LBJ School of Public Affairs; University of Texas at El Paso Center for Inter-American and Border Studies to mention some; Texas A\&M International in Laredo, Texas has the Global Initiative and a program in international nonprofit excellence. On the Mexican side El Colegio de la Frontera Norte, a think tank with presence along the Mexican border, focusing on a variety of border topics and publishes an academic journal Frontera Norte, the Universidad Autónoma de Baja California (UABC) with its journal Estudios Fronterizos; and Universidad Autónoma de Ciudad Juárez are among the universities located in border states and cities that produce knowledge about the border. It is important to mention the Association of Borderlands Studies which publishes the Journal of Borderlands Studies.

So far the analysis has focused on how power and knowledge where the border becomes an object that is socially constructed through the power of deliberation. Thus, it is important to reflect on the issue of communications power, using Castells (2007; Castells, 2013, pp. 10-53) theoretical framework, to explain how knowledge is produced and facts are being deliberated and disseminated to shape a border reality; in short, the border is a socially contested object. Barack Obama was one of the first to show the power of social media as a tool to build an organization and raise money capable of electing a president. The election of Trump, as the U.S. president, just reaffirmed the role of social media (tweeter) as an important deliberation instrument and communications power to shape a border narrative; and the electoral arena is a way to settle which one is more convincing.

Social media has changed the rules of the game of political communication; traditional media outlets now face a counter power in social media. As stated before, 
traditional mass media (TV, radio, newspapers) were considered the fourth branch of power, and a free media was considered necessary to speak not only truth to power but make power holders accountable by fact checking about the truth. Mass media was an important intermediary of facts and true between politics and the public; if the mass media did not report it an event or fact did not exists in the public opinion. However, social media has changed dramatically the role of mass media as an important filter of truth and facts; truth and facts are now deliberated not only in mass media but in the social networks. Trump succeeded making NAFTA, the border wall, undocumented migration, and drugs topics in the election using social media as a channel to deliberate and bypass traditional media. One of the criticisms is that social media facts are not accurate or truthful "knowledge"; thus calling this era post-truth politics, to the point that the Oxford Dictionary named it the 2016 international word. Social media articulates a network of people that not necessarily looks for facts to form an opinion, but rather a network that reaffirms already made opinions regardless of accuracy or lack of.

The fact of the matter is that social media vis a vis academic outlets have more power and influence in shaping people's views; the median voter does not look facts in an objective way to shape his or her opinion, the median voter rather selects facts or opinions that validate or support his or her already held beliefs about the "truth" about the border that helps him or her to act-that is practical wisdom. The U.S. election shows that almost half of the American voters and regions such as Midwestern states, where the rustbelt is located and affected by globalization forces, do indeed hold negative views of Mexico in general and NAFTA and the border in particular. Then they are willing to support policies reinforcing borders in the form of walls and fences to protect and/or regain their symbolic power and identity.

\section{Is it Desirable? And what can be Done?}

This section combines the two questions because they cannot be look at separate; the answer to whether the trend and direction is desirable or no is linked to the strategies and actions that need to follow. The answer to the question of whether is desirable is a matter of deliberation as Aristotle would suggest. Desirability, in addition to perception and reason, is one of the three aspects associated with the "soul" that leads to action, and "the origin of action is choice and that of choice is desire and reasoning with a view to an end" (Aristotle, 2009, p. 103).

Trade and environment were important elements of the border narrative and policies, from the 1980s until the events of 09/11, providing some cohesion and galvanizing action based upon cooperation and a common end. NAFTA and the creation of environmental institutions such as the Border Environment Cooperation Commission (BECC) are examples of the border governance based upon agreed goals and ends. However, since $09 / 11$ it has become more difficult to reach an agreement about goals and ends; the border and its symbolic meaning is an example of a "wicked" problem (Blanco, 1994, pp. 21-25), where neither the goals are agreed to nor social technologies to solve the problems are known; therefore, the only way out of the dilemma is through deliberation. The fact of the matter is that the narrative that has prevailed is the one advanced by the "security-industrial complex" that the border is a 
threat and out of control (Slack et al., 2016). Therefore, the desirable action would be to create a narrative that becomes a counter power (Foucault, 1980, pp. 134-145) to be able to compete successfully in the arenas (government bureaucracies, legislatures, congress, courts, elections, etc.) where truth about the border is being deliberated and settled.

There is a need to create an alternative narrative that will lead us toward a state where the border is seen as an asset or resource (Sohn, 2014) important for capitalism and capital accumulation under globalization, therefore, emphasizing "port-operation" rather than "between-port" interdiction operations (Heyman, 2012, pp. 263-264), and where civil and human rights of people are respected (Pallitto \& Heyman, 2008, pp. 327-329). In summary, a seamless border based on relational spatial relations and spaces of flows that produced shared symbolisms; instead of a material Euclidian border that emphasizes geographical physical barriers and separation. How can this desire be reached?

One strategy is to make knowledge produced in academia more relevant; not only based on sound scientific principles, but also useful in the arenas of deliberation. It is imperative to create an alternative discourse. Science and research centers can be important resources to deploy to create a different narrative; the Centers of Excellence can be employed not only to study security issues but ways to cooperate. Mexico, in the last decades, has built considerable human capital through academic institutions such as El Colegio de la Frontera Norte, Universidad Autónoma de Baja California (UABC), Universidad Autónoma de Ciudad Juárez (UACJ) among others located at the border. Mexican and U.S. institutions along border' states need to be not only centers of knowledge production but also part of the discussion in the deliberation arenas in order to influence narratives. Border research needs to be based on partnerships and intersubjective research strategies that would allow border researchers to hear and learn from other perspectives and each other.

Another strategy is to explore and replicate the Erasmus program implemented by the European Union to promote crossborder and transnational education programs, so citizens in both countries can learn from each other, and find that there are more things that bring us together than separate us. I am not aware of dual degree programs related to public policy making that would allow professionals across the border to learn how things work on both sides of the border. There is an online program offered by El Colegio de la Frontera Norte about U.S.-Mexico Border Studies whose goal is to train people that understand the border and can offer policy solutions. Therefore, there is a lack of understanding of policy process by both sides; this kind of knowledge is needed to advance a coherent agenda by binational and bicultural border people. There have been some efforts of dual degree programs that have not been sustained; for instance, a program between UABC and San Diego State University to offer a joint degree on border planning and administration. It is important to develop binational degree programs to train future leaders and policy specialists that would offer new narratives. An intermediate stage perhaps could be to increase academic exchange among faculty and students, dual credits, etc. It is important to develop crossborder human capital that would be the means not only to build a transnational professional bureaucracy but also to facilitate and influence action in the deliberative arenas.

Last strategy but not for that least important is what Mexico can do in alliance with other powerful actors. I argue that Mexico's view on sovereignty needs to be reconceptualized and stop acting as a "sensitive porcupine" (Davidow, 2004, pp. xi-xvii) 
that reacts to any minor action, and move beyond victimization discourses towards a more pragmatic approach and exercise whatever soft power (i.e. positive views the world holds of the country) it holds (Meyer, 2016). It is necessary to move beyond the Estrada' Doctrine based upon the notion of sovereignty respect and rights to self-determination of each nation and non-intervention. It is important to lobby and offer a different narrative, in the deliberation arenas where truths are formed, to the one portrayed by the "security-industrial complex". Mexico can learn a great deal from Israel. Silva-Herzog (2016) in an editorial puts the topic in a very eloquent way, regarding Trump's narrative, saying that the: Mexican government [previous to the election] has not been capable of defending an association, that is beneficial for both nations, and that also poses complex challenges. Calling names or adjectives to the aggressor [Donald Trump] is not what it is about.

In order to defend this beneficial association is necessary to form partnerships with multinational corporations, congressmen pro-Mexico and pro-NAFTA, state governors, etcetera; all the stakeholders around NAFTA and more fluid borders to become a counter power to the "security-industrial complex.

\section{Conclusions}

This article has been an attempt to use of phronesis as a methodological and analytical tool to explain re-bordering processes and dynamics taking place at the U.S.-Mexico border. It is important to remind the main question of the paper: Why the "reterritorialization" narrative of reinforcing differences and solidifying the border has prevailed, despite the fact that there is evidence (trade, foreign direct investment, etc.) showing that a more seamless border is an important economic asset for both countries? The answer to the question of why objective knowledge lack political influence in a context where "wicked problems" exist in which there is neither an agreement about the objectives and problem definition nor the social technologies to find solutions (Blanco, 1994, pp. 21-25). Thus, the only way to define the problem or reality is through deliberation and power relations where "value rationality" plays a key role in the production of knowledge. The U.S.-Mexico border was an iconic case study to undertake an analysis of how communication power plays a key role in defining reality and border policy agenda. The four guiding questions used to approach power relations allow me to deconstruct power relations to understand the making of a narrative of border reinforcement and differentiation in the form of walls and fences. After all, as Bauman suggests (2007, pp. 5-26; Bauman, 2012, pp. 1-15), borders are a tangible manifestation of a "solid" institution designed to manage fear and anxiety that outsiders cause for those "inside."

The short list of winners and losers was intended to be only illustrative not exhaustive of the entire set of border actors. The list allowed me to focus on what I considered to be the most pressing issues from my own academic bias. The future research agenda that lies ahead is to expand the list of border actors and analyze not only who wins and loses with a border barrier but how power is displayed and exercised to rationalize and produce a border reality.

The midterm elections in the U.S. in November 2018 offered once more a scenario where communications power very likely will play an important role. Trump trough 
social media capitalized politically and exploiting to his advantage the Central American migrant's caravan passing through Mexico with the hope of getting asylum in the U.S., again, migrants are portrait as "invaders" and social media and mainstream media are playing a crucial role. The midterm elections, despite the fact that democrats took control of the House of Representatives, were not as catastrophic as some experts suggests for the Trump administration. The U.S. Senate still a very powerful allied of the policy of reinforcing borders. The direction that the Supreme Court will take in the future is an open question; Trump has scored some victories in the judicial system.

This approach offered new route for inquiring about policy making and politics. Unlike traditional approaches, that assume "pure rationality", this article put at the center the role of "practical wisdom" as a form of power relations in deliberation arenas, and how these shape policy outcomes. This paper is an attempt to explain rebordering processes from a perspective of knowledge, power and communication and taking a post-positivist social sciences approach that puts the emphasis on power and communication (Bernstein, 2010; Flyvbjerg, 2001); a step forward beyond ontological objectivism and subjectivism.

\section{References}

Andreas, P. (2004). Illicit International Political Economy: The Clandestine Side of Globalization. Review of International Political Economy, 11(3), 641-652.

Aristotle. (2009). The Nicomachean Ethics. Oxford, United Kingdom: Oxford University Press.

Bauman, Z. (2007). Liquid Times: Living in an Age of Uncertainty. Cambridge, United Kingdom: Polity Press.

Bauman, Z. (2012). Liquid Modernity. Cambridge, United Kingdom: Polity Press.

Bernstein, R. J. (2010). The Pragmatic Turn. Cambridge, United Kingdom: Polity Press.

Blanco, H. (1994). How to think about social problems: American pragmatism and the idea of planning. Westport, Connecticut, United States: Greenwood Press.

Boehmer, C. R. \& Peña, S. (2012). The Determinants of Open and Closed Borders. Journal of Borderlands Studies, 27(3), 273-285.

Bourdieu, P. (2003). Language and Symbolic Power. Boston, Massachusetts, United States: Harvard University Press.

Bourdieu, P. (2014). On the State: Lectures at the College of France 1989-1992. Malden, Massachusetts, United States: Polity Press.

Boyce, G. A. (2016). The Rugged Border: Surveillance, Policing and the Dynamic Materiality of the US/Mexico Frontier. Environment and Planning D: Society and Spa$c e, 34(2)$, 245-262.

Brenner, N. (1999). Beyond State-centrism? Space, Territoriality, and Geographical Scale in Globalization Studies. Theory and Society, 28(1), 39-78.

Castells, M. (2007). Communication, Power and Counter-power in the Network Society. International Journal of Communication, 1, 238-266.

Castells, M. (2013). Communication Power. New York, United States: Oxford University Press. 
Davidow, J. (2004). The U.S. and Mexico: The Bear and the Porcupine. Princeton, United States: Markus Wiener.

Department of Homeland Security (DHS). (2016). Budget-in-Brief: Fiscal Year 2016. Retrieved from https://www.dhs.gov/sites/default/files/publications/FY_2016_ DHS_Budget_in_Brief.pdf

Flyvbjerg, B. (2001). Making Social Science Matter: Why Social Inquiry Fails and how it can Succeed Again. Cambridge, United Kingdom: Cambridge University Press.

Forester, J. (2001). An Instructive Case-study Hampered by Theoretical Puzzles: Critical Comments on Flyvbjerg's Rationality and Power. International Planning Studies, 6(3), 263-270.

Foucault, M. (1980). Power/Knowledge: Selected Interviews and Other Writings, 1972-1977. New York, United States: Random House.

Foucault, M. (2004). Security, Territory, Population: Lectures at the College de France 19771978. New York, United States: Picador Palgrave.

Fuentes, C. M. \& Peña, S. (2010). Globalization, Transborder Networks, and US-Mexico Border Cities. In K. Staudt, C. M. Fuentes \& J. E. Monárrez (Eds.), Cities and Citizenship at the US-Mexico Border: The Paso del Norte Metropolitan Region (pp. 1-19). New York, United States: Palgrave Macmillan.

Habermas, J. (1985). The Theory of Communicative Action. Volume 1. Reason and the Rationalization of Society. Boston, Massachusetts, United States: Beacon Press.

Harvey, D. (2006). Spaces of Global Capitalism. New York, United States: Verso.

Hayes, B. (2012). The Surveillance-Industrial Complex. In K. Ball, K. D. Haggerty \& D. Lyon (Eds.), Routledge Handbook of Surveillance Studies (pp. 167-175). Abingdon, United Kingdom: Routledge.

Heyman, J. (2012). Capitalism and US Policy at the Mexican Border. Dialectical Anthropology, 36, 263-277.

Heyman, J. (2017). Contributions of U.S.-Mexico Border Studies to Social Science Theory. In C. Vélez-Ibáñez \& J. Heyman (Eds.), The US-Mexico Transborder Region. Cultural Dynamics and Historical Interactions (pp. 44-64). United States: University of Arizona Press.

Lyon, D. (2010). Liquid Surveillance: The Contribution of Zygmunt Bauman to Surveillance Studies. International Political Sociology, 4, 325-338.

Meyer, L. (December 22, 2016). Construir un poder blando. Reforma. Retrieved from http://www.reforma.com/aplicaciones/editoriales/editorial.aspx?id=103703

Morgenthau, H. J. (2014). A Realist Theory of international politics. In C. Elman \& M. A. Jensen (Eds.), Realism Reader (pp. 53-59). New York, United States: Routledge.

Newman, D. (2003). On Borders and Power: A Theoretical Framework. Journal of Borderlands Studies, 18(1) 13-25.

Nunez-Neto, B. (2008). Border Security: The Role of the U.S. Border Patrol. Retrieved from http:/ /digitalcommons.ilr.cornell.edu/cgi/viewcontent.cgi?article=1577\&context=key_workplace

Paasi, A. (2010). Commentary: Regions are Social Constructs, but who or What 'Constructs' Them? Agency in Question. Environment and Planning, 42, 2296-2301.

Paasi, A. (2011). The Region, Identity, and Power. Procedia Social and Behavioral Sciences, 14, 9-16. 
Pallitto, R. \& Heyman, J. (2008). Theorizing Cross-Border Mobility: Surveillance, Security and Identity. Surveillance E Society, 5(3), 315-333.

Passel, J. S. \& D'Vera, C. (2014). Unauthorized Immigrant Totals Rise in 7 States, Fall in 14: Decline in Those From Mexico Fuels Most State Decreases. Washington, District of Columbia, United States: Pew Research Center's Hispanic Trends Project.

Ross, A. (Ed.). (1996). Science Wars. United States: Duke University Press.

Salter, M. B. (2006). The Global Visa Regime and the Political Technologies of the International Self: Borders, Bodies, Biopolitics. Alternatives: Global, Local, Political, 31(2), 167-189.

Sassen, S. (2007). A Sociology of Globalization. New York, United States: W.W. Norton \& Co.

Silva-Herzog, J. (March 14, 2016). El abandono de una voz. Reforma. Retrieved from https://www.reforma.com/aplicacioneslibre/preacceso/articulo/default.aspx?id=84205\&urlredirect=https: / / www.reforma.com/aplicaciones/editoriales/editorial.aspx?id=84205

Slack, J., Martínez, D. E., Lee, A. E. \& Whiteford, S. (2016). The Geography of Border Militarization: Violence, Death and Health in Mexico and the United States. Journal of Latin American Geography, 15(1), 7-32.

Sohn, C. (2014). The Border as a Resource in the Global Urban Space: A Contribution to the Cross-border Metropolis Hypothesis. International Journal of Urban and Regional Research, 38, 1697-1711.

Sparke, M. D., Sidaway, J., Bunnell, T. \& Grundy-Warr, C. (2004). Triangulating the Borderless World: Geographies of Power in the Indonesia-Malaysia-Singapore Growth Triangle. Transactions of the Institute of British Geographers, 29, 485-498.

Taylor, P. J. (2003). The State as a Container: Territoriality in the Modern World System. In N. Brenner, B. Jessop, M. Jones \& G. Macleod (Eds.), State/Space: A Reader (pp. 101-114). Malden, Massachusetts, United States: Blackwell Publishing.

U.S. Customs and Border Protection. (2015a). On a Typical Day in Fiscal Year 2015, CBP. Retrieved from https://www.cbp.gov/newsroom/stats/typical-day-fy2015

U.S. Customs and Border Protection. (2015b). Southwest Border Unaccompanied Alien Children Statistics FY 2015. Retrieved from https://www.cbp.gov/newsroom/ stats/southwest-border-unaccompanied-children/fy-2015

U.S. Department of Homeland Security. (2015). Welcome to the Centers of Excellence. Retrieved from https://www.dhs.gov/science-and-technology/centers-excellence

Sergio Peña

Mexican. Ph.D. in urban and regional planning from The Florida State University. He is currently a profesor-researcher in the Department of Urban Studies in El Colegio de la Frontera Norte. Reseach lines: urban and regional planning and cross-border studies. Resent publications: Fuentes, C., Peña, S. \& Hernández, V. (2018). La Medición Multidimensional de la Pobreza a Nivel Intra-Urbano en Ciudad Juárez, Chihuahua (2012). Estudios Fronterizos, 19(38). 